\title{
Management of Epidemics in Tropical Countries
}

\section{Shahzad Shaukat* \\ Virology Department, National Institute of Health, Islamabad, Pakistan}

*Corresponding author: Shahzad Shaukat, Molecular Biologist, WHO Regional Reference Laboratory for PEI, Virology Department, National Institute of Health, Islamabad, Pakistan, Tel:+92-321-5167936; E-mail: vibgyors@yahoo.com

Received date: July 27, 2016; Accepted date: October 31, 2016; Published date: November 01, 2016

Copyright: ( 2016 Shaukat S. This is an open-access article distributed under the terms of the Creative Commons Attribution License, which permits unrestricted use, distribution, and reproduction in any medium, provided the original author and source are credited.

\section{Editorial}

The diseases that occur solely or principally, in the tropical and subtropical regions are called as Tropical diseases. These diseases are less or not prevalent in temperate climates because of the occurrence of a cold season that controls the insect population by forcing hibernation. Public health is the art and science of preventing disease, promoting health and prolonging life through organized efforts of the society. It plays an important role in managing, mitigating and preventing the spread of diseases. Journal of Tropical Diseases and Public Health is an international open access peer reviewed journal that publishes high quality articles related to current research, new concepts, novel diagnosis and approaches of early detection, control and treatment of the tropical diseases and practice of public health. The scope includes all aspects of public health and tropical diseases. The current volume number 4 issue 3 of the journal had published ten high quality research articles.

In the research article Tamirat et al. identified the determinants of insecticide treated net (ITN) use as part of malaria preventive behaviour among households in Maji district of Ethiopia. Their study revealed that ITN use was low in Maji district and the efforts should be revised on individual perception on ITN use. Authors suggested strengthening the health education and behaviour change activities for improving knowledge on the disease prevention [1]. Nakeel et al., in their research article conducted sero-epidemiological survey on leptospirosis, brucellosis, and Q-fever in humans and livestock and analyzed the associated risk factors in Kajiado county-Kenya. Authors found that that the brucellosis and Q-fever are enzootic in the study area and leptospirosis present in cattle poses a serious public health problem [2]. Kindie et al. determined the prevalence of intestinal parasitic infections in HIV-infected patients undergoing anti-retroviral therapy (ART). Authors suggested that regular de-worming and health education about personal hygiene is very essential for HIV-infected patients [3].

Diop et al. reviewed the epidemiology of Zika virus infection and described the recent trend in its epidemics. Authors concluded that Zika virus infection has been underreported and under-diagnosed in disease-endemic settings. Authors suggested the laboratories to modernize the technology to differentiate Zika infection from other arboviral dengue-like infections. Authors also emphasized the need for anantiviral therapy and vaccines to fight Zika virus [4].

Siengwattana et al's research article described the nosocomial diarrhea in the tertiary care hospitals, and Bhattacharya et al., dealt with malaria management. While Sricharoenchai et al., discussed the children's respiratory syncytial virus (RSV) associated lower respiratory tract infection (LRTI) and their epidemiology, Abraham et al., described the peritoneal dialysis in India. Kangbai and Mukherjee et al.discussed the cell phone-based syndromic surveillance data for Ebola and analyzed the effect of sports and fitness program against non-communicable disorders among high school students respectively [5-10].

\section{References}

1. Tamirat A, Geremew M, Abamecha F, Wollancho W (2016) Knowledge, Attitude and Practice about Malaria in Maji District, Bench Maji Zone, Southwest Ethiopia. J Trop Dis 4: 217.

2. Nakeel MJ, Arimi SM, Kitala PK, Nduhiu G, Njenga JM, et al. (2016) A Sero-epidemiological Survey of Brucellosis, Q-Fever and Leptospirosis in Livestock and Humans and Associated Risk Factors in Kajiado CountyKenya. J Trop Dis 4: 215.

3. Kindie Y, Bekele S (2016) Prevalence and Risk Factors for Intestinal Parasite Infections in HIV/AIDS Patients with Anti-Retroviral Treatment in South West Ethiopia. J Trop Dis 4: 210.

4. Diop D, Rambe DS, Sanicas M (2016) Zika Virus Disease Epidemics. J Trop Dis 4: 208.

5. Siengwattana $\mathrm{P}$, Poovipirom $\mathrm{N}$, Chayakulkeeree $\mathrm{M}$, Kiratisin $\mathrm{P}$, Maneerattanaporn M (2016) Factors Determining Physicians' Decision Making In Treatment and the Outcomes of Nosocomial Diarrhea in a Tertiary Care Hospital: A Prospective Cohort. J Trop Dis 4:209.

6. Bhattacharya D, Pradhan PK (2016) Tongue is the Face of the Malady? Differentiating in Desolate Distance: Locus-Tropical Field India. J Trop Dis 4: 211.

7. Sricharoenchai S, Palla E, Pasini FL, Sanicas M (2016) Epidemiology of Respiratory Syncytial Virus Lower Respiratory Tract Infection (Rsv-Lrti) In Children in Developing Countries. J Trop Dis 4: 212.

8. Abraham G, Gupta A, Prasad KN, Rohit A, Billa V, et al. (2016) Microbiology, Clinical Spectrum and Outcome of Peritonitis in Patients Undergoing Peritoneal Dialysis in India: Results from a Multicentric, Observational Study. J Trop Dis 4: 213.

9. Kangbai BJ (2016) Regression Modelling and Analysis of Cell phoneBased Syndromic Surveillance Data for Ebola in Sierra Leone. J Trop Dis 4: 214 .

10. Mukherjee S, Hasrani SS, Saini RC (2016) Analysis on the Awareness of Non-Communicable Disorders and its Prevention through Sports and Fitness Program among High School Students of Mekelle. J Trop Dis 4: 216. 